\title{
A Critical Discourse Analysis of Transitivity Variation between Genders in Selected Public Political Speeches: A corpus-based Study
}

\author{
Dalia Kamal Abdel Hamied Hassan*
}

\section{Professor: Shaker Rizk **}

\author{
Dr. Marwa Nasser***
}

\begin{abstract}
This research is a corpus based critical discourse analysis of selected political speeches by Hillary Clinton, Michael Obama, Halimah Yaccoub, Donald Trump and others. The aim of the study is to analyze the difference between male and females' political discourses to prove the language variation existence between genders in standard public political speech. The grammatical features found in the analysis are analyzed through Halliday's transitivity system. Halliday's transitivity focuses on examining the processes types and their circumstances and participants. Throughout the analysis, special attention is paid to the way those verb processes are used by the speakers that portray the distinction between male and female speeches. It is also proved that Halliday's Transitivity is very effective in showing the similarities and differences between females' and males' speeches.

Keywords: Critical Discourse Analysis, Transitivity, Gender Variation, Corpus Analysis, Political speech
\end{abstract}

*Master's Researcher - Department of English - Canadian Higher Institute dalia_kamal@ ciccairo.com

Professor of Linguistics Faculty of Arts English Department Suez University.

$* *$

Assistant Professor of linguistics Faculty of Women for Arts, Science and Education English

$* * *$ Department, Ain Shams University. 


\section{Language \& Literature}

\section{I- Introduction}

This is a critical discourse analysis of selected political speeches of some females' and males' politicians from different cultures i.e. European, American, African and Asian. Hillary Clinton, Michelle Obama, Julia Gillard, Halimah Yacoub are the representatives for the female gender, while Donald Trump, Michael D Higgin, Cyril Ramaphosa and Antonio Guterres are the male's representatives. The speeches are chosen according to two main themes to be precisely examined. The first is the theme of accepting the nomination and the second is the theme of women role and feminine issues in society. This study aims to spot the light over the different verbal choices variation between males and females' standard political speeches. It aims to explain how those verbal choices signifies different aspects. The study also shows that although the selected speeches are political ones that use the standard form of the language; there is still a variation that occurs due to the difference in gender. A lot of studies have been done examining the political discourses of those politicians; however, this study is different from the other previous studies in the sense that it focuses on examining the verbal variation between genders using corpus linguistics and in the light of Halliday's transitivity.

\subsection{Objectives of the study}

a- To uncover the verbal choices differences and similarities between male and female politicians.

b- To find out the grammatical differences that are associated with the change of the topic of speech.

c- Considering the fact that the eight speakers are from different nationalities and cultural backgrounds, exploring the ideological side of those speakers is another objective. 


\section{Language \& Literature}

\subsection{Significance of the Study}

The study is a corpus analysis of selected political speeches in terms of form and function. Data is examined quantitatively to determine the most and the least frequent verbal items, and then qualitatively by drawing significant interpretations of the frequency of these items. The main framework in this study is the Halliday's Transitivity theory.

\subsection{Statement of the Problem}

Examining political discourse started to overspread in our societies since we have access to a massive stream of political messages through media. Politics is reflected through ideas, ideologies, visions, and arguments which are presented through language. The goals of giving a political speech ranges between a message to inform, or a message to persuade, or a message to gather acceptance. Consequently, it seems very problematic to uncover the variation that exists between both male and females since their goal is seemingly the same. Both genders aim at giving a high good impact over their listeners and followers; for that reason, it seems that depicting a variation that shows the gender variation as represented in verbal choices used by both genders seem a kind of problem to the researcher.

\subsection{Research Assumptions}

The research assumes that

1- Halliday's Transitivity is very effective in reflecting the gender distinction feature.

2- Females' and males' politicians use language differently in their public political speeches.

\subsection{Research Questions}

This study attempts to find answers to the following questions: 


\section{Language \& Literature}

1- What are the areas of verbal differences between the speakers of both genders?

2- What are the areas of verbal similarities shared by the speakers of both genders?

3-What are the processes types affected by the change of the theme of the speech?

\subsection{Data Collection}

The corpus of the study consists of different political speeches for different gendered world-wide political leaders. On the one hand, the female speeches are represented via four speeches uttered by Hillary Clinton, Michael Obama, Halimah Yacop and Julia Gillard. On the other hand, the voice of male speakers is represented through four speeches uttered by Donald trump, Cyrial Ramaphosa, Michael D Higgins and Antonia Guterres. The selected data are gathered from different websites that are specialized in publishing political speeches transcripts.

1- Hillary Clinton (Acceptance speech) 29/7/2016 (American) www.politico.com/story/2016/full-text-hillary-clinton-dnc-speech-226410

2- Michael D Higgins (Inaugural speech) 11/1112018 (Irish) https://www.independent.ie/irish-news/read-michael-d-higgins-inaugurationspeech-in-full-37516720.html

3- Halimah Yacob (Acceptance speech) 13/9/2017(Singaporean) www.straitstimes.com/politics/halimah-yacob-declared-president-electtranscript-of-acceptance-speech

4- Donald Trump (Victory speech) 9/9/2016 (American) https://edition.cnn.com/2016/11/09/politics/donald-trump-victoryspeech/index.html

5- Julia Gillard (Misogyny speech) 2012(Australian) https://www.smh.com.au/politics/federal/transcript-of-julia-gillards-speech20121010-27c36.html

6- Michelle Obama (on the international women day speech) 8/3/2016(American) 


\section{Language \& Literature}

https://obamawhitehouse.archives.gov/the-press-office/2016/03/08/remarksfirst-lady-let-girls-learn-event-celebrating-international

7- Cyril Ramaphosa (on the national women day speech ) 9/8/2019(South African)

https://www.gov.za/speeches/president-cyril-ramaphosa-addresses-nationalwomens-day-cele bration-9-aug-8-aug-2019-0000

8- General Antonio Guterres (On Gender Equality) 9/3/2020 (Portuguese) https://www.youtube.com/watch?v=zMWL9k3Sjcc

\section{II- Literature Review}

Many theories have been proposed to explain and justify what controls human language. Although many previous studies cover a wide variety of such theories, this study is composed of three main points which emerge gradually throughout the literature reviewed. These points are: general definition of key terms, related studies and the contribution of the present research.

2.1 Definitions of key terms: This section demonstrates some of the basic terms and their definitions that are related to the present study.

2.1.1 Computational linguistics (CL): According to Schubert (2020) "it is the scientific and engineering discipline concerned with understanding written and spoken language from a computational perspective, and building artifacts that usefully process and produce language, either in bulk or in a dialogue setting"

2.1.2 Corpus linguistics: A corpus is a "collection of linguistic data, either written texts or a transcription of recorded speech, which can be used as a startingpoint of linguistic description or as a means of verifying hypotheses about a language" (Crystal, 2008, p. 86)

2.1.3 Critical Discourse Analysis (CDA): Mullet (2018, p116-142) defined it as a qualitative analytical approach for critically describing, interpreting, and explaining the ways in which discourses construct, maintain, and legitimize social inequalities. 
Buhuth Journal

Second Issue- part two (2021)

\section{Language \& Literature}

2.1.4 Key word in context (KWIC): According to Merriam Webster (n.d) it is a computer-generated index alphabetized on a keyword that appears within a brief context.

2.1.5 Linguistic Variation: According to Nordquest (20) states that it "refers to regional, social, or contextual differences in the ways that a particular language is used".

2.1.6 Sketch Engine: According to Kilgarriff et al. (2014) sketch engine is the ultimate tool to explore how language works. Its algorithms analyze authentic texts of billions of words (text corpora) to identify instantly what is typical in language and what is rare, unusual or emerging usage.

2.1.7 Transitivity system: According to Halliday (1994) "transitivity is a system that construes the world of experience into a managable set of process types" (p.106).

After displaying the most important key terms used in the study, the following section displays the most related studies that examined the variations between genders which is the main topic in the current study.

\subsection{Related Studies}

This section is divided into three subsections that tackle the previous related studies. First is the gender variation in related studies, then transitivity in related studies ending by corpus based related studies.

\subsubsection{Gender variation in related studies}

Examining any discourse from a gender perspective paves the way to understanding how gender affects behaviors, evaluations, and outcomes for both genders. Gender differences is one of the main factors that affects language variation. It was assumed and proved in many previous studies as in Anna (2018), Zemojtel et al. (2017) and Božić (2016) that each gender has its own features which may result in a speech production that appears to be different from that 


\section{Buhuth Journal Language \& Literature}

Second Issue- part two (2021)

produced by the other gender. Božić (2016, p.202) tackled the linguistic variation happened in his selected data from a gender lens. In his thesis he found that political discourse could be a rich platform emphasizing the variation of language between males and females. He stated that by applying the Critical Discourse Analysis approach, he found that "the gender differences appear in the ways some word categories were used" (p.202). Moreover, Anna (2018, p.62) examined gender discourse in newspapers' articles written about male and female politicians. She stated that newspapers have an important role in creating gender discourses, perceptions on gender and gender variation that is because newspapers are regarded as a trustworthy source of information by a lot of people even in the current time, where the traditional media faces a deterioration in their popularity. Her examination resulted in finding that "the collocates of the female politicians would include more family-related words and more appearance-related words than their male colleagues collocates" (p.62). Another research in the same track was that of Romaniuk (2016) in which she studied gendered discourses in media, and one of her case studies was about Hillary Clinton's presidential bid in 2007-2008 and namely "her laughter that was dubbed a "cackle" by mainstream media". She used corpus methods to study "the collocational profile of the term "cackle" and came to the conclusion that the word has a very negative semantic prosody", i.e. it is associated with very negative and unpleasant things (2016, p.abstract). She studied both the collocates for the term "laugh" and the collocates for the term "cackle", and found out that "while "laugh" has adjective collocates ranging from positive to negative ones, the collocates for "cackle" were all negative" (p.544). More examples of how politicians are perceived differently due to their gender was found in the study performed by Żemojtel et al. (2017) in which they examined how people reacted to politicians involved in different scandals. The results showed that male politicians were not judged in a harsh hard way as female politicians are, and also that scandals had an effect on how the morality and behaviors of these males and females politicians were seen, "but with female politicians it also affected the notion of their competence" (p.138). Political debates are also great source for examining gendered language. Shaw (2002) 


\section{Language \& Literature}

showed that the linguistic practices of politicians in one of the oldest and most powerful of all British institutions: The House of Commons are a great source of examination. After the general election of 1997 record numbers of women were elected to parliament. This rapid increase in women's representation led to much speculation in politics and the media about how new women MPs (members of the parliament) would adapt to and change British politics. At the same time, it is clear that men and women MPs are not treated equally. Women are marginalized by sexist barracking within the chamber and portrayed negatively by the media (p.2). She concluded that:

The differences between the two assemblies show that women MSPs participate in more linguistic practices than their counterparts at Westminster. Their involvement in adversarial and humorous exchanges suggests that in the Scottish Parliament women are not 'interlopers' but members who feel that they belong to the institution on equal terms with men (p.276).

Childs (2000) also stated in her analysis of the recruitment and representation of women MPs in the 1997 parliament:

Points to notions of acceptable and unacceptable, legitimate and illegitimate forms of language style appropriate to politics. In these oppositions, the former are associated with male language, modes of interaction and men MPs, and the latter with women's language, modes of interaction and women MPs (2000, p. 69).

Totibadze (2017, p.39) found in his research that it has been claimed that metaphors from the source domain of WAR, SPORT and BUILDING are openly related to men, therefore and with no doubt belong to males' speech types, than females'. 
Gender controversies on media and communication studies are much discussed topics for long years. A lot of scientific studies has been done in these areas. Schwartz et al (2013. P.9) analyzed 700 million words, phrases, and topic instances collected from the Facebook messages of 75,000 volunteers, who also took standard personality tests, and found striking variations in language with personality, gender, and age. The researchers of this article had found that "females used more emotion words (e.g., 'excited'), and first-person singulars and they mention more psychological and social processes (e.g., 'love you' and 'v3' -a heart). Males used more swear words, object references (e.g., 'Xbox' and swear words)" Furthermore, gendered language in social media was examined by Schwartz et al (2013) who found that:

Since gender is a familiar variable, it functions as a nice proof of concept for the analysis. In agreement with past studies, we see many ngrams related to emotional and social processes for females (e.g. 'excited', 'love you', 'best friend') while males mention more swear words and object references (e.g. 'shit', 'Xbox', 'Windows 7'). We also contradict past studies, finding, for example, that males use fewer emoticons than females. Also, worth noting is that while 'husband' and 'boyfriend' are most distinguishing for females, males prefer to attach the possessive modifier to those they are in relationships with: my wife or my girlfriend (p.5).

Gender is a wider concept than sex and a gender perspective in medicine implies that living conditions, positions in society and societal expectations about 'femininity' and 'masculinity' should be considered along with biology in professional relationships, as well as when theorizing about women and men. Unawareness of gender aspects among health-care professionals and medical researchers can lead to gender bias. In that domain Risberg et al (2006, p.4) have revealed in their article 'Gender perspective in medicine: a vital part of medical scientific rationality' a useful model for comprehending structures and hierarchies within medical science that there is a gender bias in many areas of clinical and academic medicine. 


\section{Buhuth Journal Language \& Literature}

Second Issue- part two (2021)

Biber (2000) found that there are features associated to female speeches in his research "Historical Change in the Language Use of Women and Men" stating that some general features were found that are related to female speeches. Those features are:

1- In mixed gender settings, females tend to speak less than men. 2-

Females focus more on the personal aspects of conversation while males tend to be more active in delivering just information. 3Females tend to be more tentative than men in their use of language in both spoken and written discourses. 4- Females use less persuasive strategies and more narrative strategies to emphasize (p.21).

Moreover, Dahbi (2003, p.2) talked about gender in her research that is entitled 'Gender Differences in Language? An Investigation of Gender-Related Differences in Classroom Conversations'. She found many differences between males and females' speeches at so many levels of language. Actually, a number of syntactic grammatical structures, lexical issues, phonological issues and conversational techniques were found to be sex oriented i.e. related to one gender and not the other. Females' speech has been assigned the feature of being “inconclusive, indefinite, tentative, overtly polite and cooperative". Males' speech, on the contrary, has been recognized as "complex, powerful, direct, definite and authoritative" (p.2).

Literature is also another field in which gender has been examined thoroughly. Najeem (2017) stated in his research that:

Male authors integrate and organize meanings into clause complexes more than simplexes, and that female writers use more of clause simplexes than clause complexes. It was also found that male authors used more of embedded clauses than female authors, with the overall implication that the language of male authors tends to be more syntactically and semantically complex than that of female authors (p.284).

\subsubsection{Transitivity in related studies}




\section{Language \& Literature}

Studies have established gender-based variations in human's use of language, particularly in the areas of grammar and lexis. Emilia et al. (2017) in their research paper focused on the topic of gender in EFL classroom through the transitivity analysis, particularly in Indonesian context. Moreover, Cristina's (2001) main objective was to examine the language used by the hero and the heroin in the play 'Pygmalion' by Bernard Shaw by applying the lexico-grammatical category of transitivity. She concluded from analyzing the text by the processes system that "the male character is the doer of more practical actions than the female".

Moreover, public speech genre analysis was the focus of many linguists because they are regarded as an important source that can discover the nature of language due to their organized and well-established structure. Yujie, and Fengjie (2018) study focused on the analysis of the linguistic features of the American elected President Donald Trump's Inaugural Address using the transitivity model of analysis. Consequently, the quantitative analysis has resulted in that the transitivity system in SFG is an effective method in encoding and decoding this political public speech. Wang (2010) also applied the transitivity analysis on Obama's speeches which shows that the material process in Obama's speeches is the highest of all. Through using the material process Obama succeeded in reflecting the achievements of the government.

\subsubsection{Corpus based related studies:}

Corpus linguistics as a new discipline employs corpus which is computerized collections of spoken and written texts and then analyze them to find the irregularities, mistakes, and patterns according to the goal of the research. Stubbs (2001), for instance, focused his research on the corpus based lexical analysis. He presented words and phrases, how they are used, their meanings, connotations, and denotations. Throughout his research, he provided answers to the questions concerned with how the meanings of words depend on their different uses. Bang (2003) found that the corpus tool is a successful one in 


\section{Language \& Literature}

analyzing his corpora. In his research Bang found that "a sense of tension seems to sum up the representation of the two countries in the corpus"

According to Adelakun (2013) the corpus approach is found to be of a great importance in political discourses. In order to get the implied meaning and intention behind political speeches and scripts, one needs to examine them in or compared to large number of corpora. Moreover, Danijel (2014) used the corpus tool to examine pronouns, modal auxiliaries, metaphors, and euphemisms in certain 9/11 and warfare speeches delivered by the last two American Presidents, George Bush and Barack Obama, from 2001 to 2013 in his research.

\subsection{Significance of the study}

It appears vividly that on the level of critical discourse analysis, many researchers have tried to analyze the linguistic features of political speeches using a corpus-based approach. In addition, many others experienced the gender variation in political discourses following a quantitative or a qualitative method of analysis to examine one culture background discourse. However, nearly no research was found exploiting both the quantitative and the qualitative analysis in a single research to examine speeches of different cultured figures for the sake of getting a comprehensive view by frequency and significance that are the result of a gender difference. Thus, the current research intends to offer a comprehensive study that signifies the differences in the verbal choices produced by different gender politicians of different nationalities through a quantitative and qualitative analysis and by the help of Sketch engine corpus tool.

\section{III-Theoretical Framework}

This section depicts the theoretical frame of the current study. A critical discourse analysis for selected public political speeches for several worldwide politicians are critically analyzed following the Hallidayan Transitivity system. The main goal of the analysis is to prove a gender variation between male-female 
Buhuth Journal

Second Issue- part two (2021)

\section{Language \& Literature}

speeches through processes analysis on the light of the Hallidayan transitivity and with the help of Sketch engine corpus tool to get statistical results.

\subsection{A historical overview of Critical Discourse Analysis}

Discourse analysis deals with a text as either written or spoken. Discourse analysis (DA), also called discourse studies, was emerged during the 1970s as an academic field. DA is a very general term for the study of the ways in which language is used between people whether written or spoken texts. After that, Critical discourse analysis (CDA) emerged from the school of critical linguistics (Kress \& Hodge, 1979; Fowler et al., 1979) which was based upon Halliday's $(1978,1985)$ systemic functional linguistics and theories of ideologies (Fairclough, 1993)

According to Williamson et al. (2018), CDA deals with linguistic and psychosocial approaches in a different way by analyzing the data from a critical scope. These analyses examine the discourse but also ask about the role of the person who utters or writes that discourse. Williamson et al stated that "CDA examines the dominant and subordinate discourses on offer in society, and explores notions of resistance and appropriation of discourses among various social actors" (p. 455).The origin of CDA lies in Rhetoric, Text linguistics, Anthropology, Philosophy, Socio-Psychology, Cognitive Science, Literary Studies and Sociolinguistics, as well as in Applied Linguistics and Pragmatics. In the same domain, Wodak (2001) states that:

CDA fundamentally is concerned with analyzing opaque as well as transparent structural relationships of dominance, discrimination, power and control as manifested in language. In other words, CDA aims to investigate critically social inequality as it is expressed, signaled, constituted, legitimized and so on by language use (or in discourse). Three concepts figure indispensably in all CDA: the concept of power, the concept of history, and the concept of ideology (pp. 2-3) 
According to Blommaert \& Bulcaen (2000), Sheyholislami (2015), \& North (2014), the most recent tenets of CDA in the 1970s are mainly based on Michael Halliday's Methodology of "systemic-functional and social-semiotic linguistics" (Blommaert \& Bulcaen, 2000, p. 454). Consequently, the study follows the Hallidayan systemic functional grammar approach which assumes that language in texts always functions ideationally in the representation of experience and the world, interpersonally with regard to social interaction between participants in discourse, and textually in connecting parts of a text together into a coherent whole and connecting texts to its situational contexts.

The following section deals with Halliday's theory which is the main framework of the current study.

\subsection{Halliday's Systemic Functional Grammar}

Halliday's systemic functional grammar can be used to explore the hidden deep meaning of discourse, and to understand and interpret the semantic and stylistic features of the text. (Yan, 2005, p.5). Consequently, systematic functional. "SFG is the study of the relationship between language and its functions in social settings. It is also known as SFL, systemic functional grammar, Hallidayan linguistics, and systemic linguistics". Chappell (2013) asserts that systemic refers to the fact that when using language, one makes choices from a group of options. This is opposite to the common view of grammar as sets of rules. Functional view that when the person makes a choice from those options, he/she is doing so in order to achieve a communicative target. Moreover, Grammar simply refers to the fact that there is an overall organization to all of these possible options.

According to Halliday (2014, p.22), when people speak or write, they produce text; and text is what listeners and readers engage with and interpret. The term 'text' refers to any production of language, in any medium, that conveys meaning; one can characterize text as language functioning in context. Yumin $(2009$, p.10) also states that three main kinds of meanings are used respectively in the structure of language: ideational, interpersonal, and textual. These three elements are also 


\section{Language \& Literature}

known as meta-functions; the categories that forms the basis of the systemic functional grammar theory. Thi (2017, p. 209) states that SFG connects "language", "mind" and "the world".

Thi (2017) states that:

Halliday understands and grasps the inter-relationship of language, mind and the world and applies it in his SFG, especially in three metafunctions. The core idea of SFG is the three distinct modes of metafunction namely: Interpersonal, Textual and Experimental (ideational), and each meta-function has its own system of choices (p.209).

\subsubsection{The Ideational or experiential Meta-function}

The ideational meta-function is the second meta-function in this study. It is through this function that the speaker or writer reflects by language his experience of the real world. This function includes: his reactions, cognitions, and perceptions, and also his linguistic acts of speaking and understanding (Halliday, 1997, p. 332). In other words, this function is to present new information, to communicate a content which is common to the hearer.

According to Halliday \& Matthiessen (1999):

Ideationally, the grammar is a theory of human experience; it is our interpretation of all that goes on around us, and also inside ourselves. There are two parts to this: one the representation of the processes themselves, which we refer to as the "experiential"; the other the representation of the relations between one process and another, and it is this that we refer to as the "logical". The two together construe the "ideational" meta-function, whereby language construes our experiential world (p.511).

It is through this function that the speaker or writer expresses through language his experience of the real world; and this includes his experience of the 


\section{Language \& Literature}

internal world of his own consciousness: "his reactions, cognitions, and perceptions, and also his linguistic acts of speaking and understanding" (Halliday, 1997, p. 332). Eggins (2011) explains that the ideational strand of meaning involves two components: that of experiential meaning in the clause, and that of the logical meaning between clauses in clause complexes. Experiential meaning is expressed through the system of transitivity or process type (p.207).

\section{A- Transitivity system}

According to Gerot and Wignell (1994), "Transitivity is a system that explores the clause in its circumstances, process, and participants"(p.52). Khumairoh (2017) also states that transitivity analysis is used for the purpose of understanding the language of speakers and writers. It examines the structure of sentences which are represented by processes, the participants and the circumstances (p7). Researchers have tried to expose that language structures can produce certain meanings which are not always clearly offered for readers. In the transitivity system, there are six types of process, namely: material, mental, relational, verbal, existential, and behavioral. The following table shows the process types with their participants:

Table(1) Halliday’s Work

(Halliday \& Matthiessen, 2014, P.311)

\begin{tabular}{lll} 
Process type & \multicolumn{1}{c}{ Category Meaning } & Participants \\
\hline Material: & "doing" & Actor, Goal \\
Action & "doing" & Beneficiary, Range \\
Event & "happening" & \\
\hline Behan & "behaving" & Behaver
\end{tabular}


Buhuth Journal

Second Issue- part two (2021)

Language \& Literature

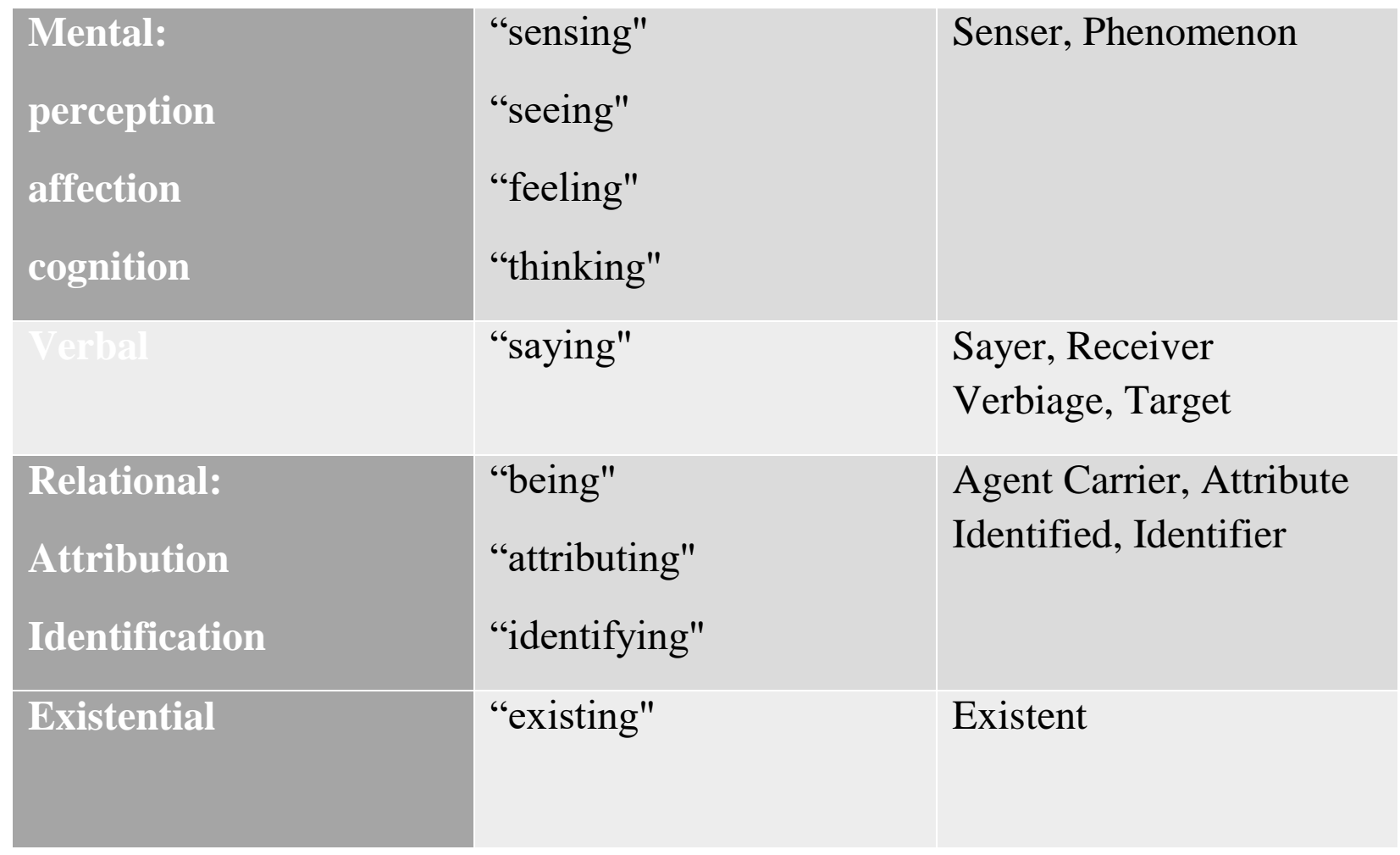

\section{I- Material process}

II-

Kurniani (2017) material processes are processes of material doing. He expresses the idea that some entity did a physical action which may be done to some other entity. So clauses with a material process basically have a doing (process) and doer (participant). The entity who or which do something is referred to as the actor. The entity to which the process is extended or directed is referred to as the goal. This is clear in the following example that is represented through a table showing the actor in the first column, the material process in the second column and the goal in the third and final column. 
Table(2)Material process

Kurniani (2017)

\begin{abstract}
The exhausted
Dropped

his pack

\section{bushwalker}

\section{Participant: Actor}

Process: material

Participant: Goal

\section{III-Mental Process}

It expresses meaning of thinking or feeling (Halliday, 1994, p.114). Emilia states that the mental processes can be classified into three classes: Cognition (processes of thinking, knowing, and understanding), Affection (Processes of liking, fearing), and Perception (Verbs of seeing and hearing) (Emilia, 2014, p.153). The following tables show the analysis of the different types of mental processes analysis.
\end{abstract}

Table (3) Mental process 1

\begin{tabular}{|l|ll}
\hline Senser & Mental Process & Phenomenon \\
\hline Mr. Kurtz & seemed to be puzzled & by this news
\end{tabular}

Table 4. Mental Process 2

\begin{tabular}{|c|c|c|}
\hline Senser & $\begin{array}{l}\text { Mental process } \\
\text { (Cognition) }\end{array}$ & Phenomenon \\
\hline No one & would have served & me better. \\
\hline
\end{tabular}

Table 5. Mental process 3

\begin{tabular}{|c|c|c|}
\hline Senser & $\begin{array}{l}\text { Mental Process } \\
\text { (Perception) }\end{array}$ & Phenomenon \\
\hline The air & Seemed Condensed & into a mournful gloom. \\
\hline
\end{tabular}




\section{Language \& Literature}

\section{IV-Verbal process}

They are the processes of saying, "These cover all categories of saying, not only in terms of modes of saying (saying, asking, stating, arguing), but also semiotic processes that are not verbal (showing and indicating)" (Martin et al. 1997, p.108). The following tables show different analyzed examples to verbal process.

Table 6. Verbal process 1

$\begin{array}{llll}\text { Sayer } & \text { Verbal process } & \text { Receiver } & \text { Verbiage } \\ \text { I } & \text { have told } & \text { him } & \text { The truth }\end{array}$

Table 7. Verbal process 2

\begin{tabular}{lll} 
Receiver & Verbal process & Verbiage \\
I & was warned & To be more careful \\
\hline
\end{tabular}

\section{V- The Behavioral Process}

They are processes of psychological behavior. According to Halliday, (1994) "behavioral processes are process of (typically human) physiological and psychological behavior, like breathing, coughing, smiling, dreaming and staring." This process is semantically described as a 'half-way house' between mental and material process. The following table shows an analyzed example for a behavioral process (p.139).

Table 8. Behavioral process

\begin{tabular}{l|ll} 
Behaver & Behavioral Process & Circumstances: Location \\
He & is dancing & around the fire
\end{tabular}

\section{VI-Existential Process}

Rayhan (2011) states that "It is the process of happening. These clauses typically have the verb be, or some other verb expressing existence, such as exist, 


\section{Language \& Literature}

arise, followed by a nominal group functioning as (Existent)" (p.28). The following table shows an example of an existential process.

Table 9. Existential process

\begin{tabular}{lll} 
& Existential Process & Existence \\
There & Was & a storm \\
\hline
\end{tabular}

\section{VII- Relational Process}

Halliday (2004) states that "Relational clauses serve to characterize and to identify"(p.210). The relational clause is realized by the verb 'Be' in the simple present or past. These types are of two modes: the modes of attributive and identifying. The attributive clauses indicates class membership by ascribing an attribute to some entity (the Carrier and the attribute). The identifying clauses indicate some attribute to an identity (Halliday 1994, 2004). The following tables show two different analyzed examples for the relational process. The first example represents the identifying relational process, while the second indicates the attributive relational process.

Table 10. Relational process 1

\begin{tabular}{lll} 
Identified & Relational Process (identifying) Identifier \\
We & are & one nation \\
\hline
\end{tabular}

Table 11. Relational process 2

\begin{tabular}{lll} 
Carrier & $\begin{array}{l}\text { Relational process } \\
\text { (attributive) }\end{array}$ & Attribute \\
\hline She & remained & The prime minister \\
\hline
\end{tabular}

\subsection{Corpus Linguistics}




\section{Buhuth Journal Language \& Literature}

Corpus Linguistics, as an important area of CL, provides large quantities of language databases accumulated in a systematic manner from various fields of actual language use following some statistical methods and techniques of data sampling. Furthermore, it provides some sophisticated devices to analyze these corpora to extract linguistic data, examples, and information necessary in applied linguistics, applying this data and information in various fields of human knowledge.

A corpus is a collection of linguistic texts that are selected and ordered according to some explicit linguistic criteria defined by the users in order to be used as a sample of a language. Computer software's used within the field of 'Corpus Linguistics' are designed to contain millions of words compiled from diverse text types across many variations to encompass the diversity a natural language exhibits through its multifaceted use. Mcenery and Wilson (1996) have divided corpus in a classification which is characterized by its characteristics stressing that: Loosely," a corpus refers to anybody of text", most commonly "it refers to a body of machine-readable text", and strictly "it refers to a finite collection of machine-readable texts sampled to be maximally representative of a language or a variety of it". This means that "corpus is a systematic computerized collection of authentic language used for linguistic analysis" (p.215).

According to Leech (1992), corpus linguistics is different from any other kind of linguistics, as it does not represent "a domain of study, but rather a methodological basis for pursuing linguistic research" (p.105). In his paper entitled "Corpora and Theories of linguistic performance" Leech (1992) argues that computer-based corpus research will be considered a new paradigm of research denying the fact that it can be regarded a mere technique or method. "Corpus linguistics always analyzes corpus data both quantitatively and qualitatively in order to explain and interpret patterns rather than just count them" (Biber et al., 1998, p.4). 


\section{Buhuth Journal Language \& Literature}

Pekosy and Harmoglu (2017) studied the resemblance of the language learning course books in Turkey to authentic language spoken by native using sketch engine software. They found that language learning books have little similarity to spoken language in terms of certain grammatical items (p.287). Moreover, Kilgarriff et al. (2015) used Sketch engine software in their language research. They expressed the idea of using corpora in language research, and sketch its history, first in linguistics, then in language learning and teaching.

\section{IV-Methodology}

This section is devoted to the methodology. It is composed of four different sections. Research methodology, the data sources, the data collection, and procedures of analysis.

\subsection{Research Method}

The study focuses on the quantitative and qualitative approaches to describe and highlight the similarities and differences between male and female political speeches. The qualitative research approach creates wider understanding of behaviour. De Vaus (2014) states that qualitative research approach provides abundant data about real life people and situations (p.6). The quantitative research approach is regarded as the use of statistical data as a tool for saving time and providing statistical information that enables qualitative analysis. Bryman (2001) argues that "quantitative research approach is the research that places emphasis on numbers and figures in the collection and analysis of data (p.20). It is to be noted that the statistical quantitative analysis is obtained by using Sketch Engine corpus software (2020) https://www.sketchengine.eu/.

\subsection{Data Sources}

The corpus of the study consists of different political speeches for different gendered world-wide political leaders. As stated above, the female speeches are represented via four speeches uttered by Hillary Clinton, Michael Obama, Halimah Yacop, and Julia Gillard. On the other hand, the voice of male speakers is represented through four speeches uttered by Donald trump, Cyrial Ramaphosa, 


\section{Language \& Literature}

Michael D Higgins, and Antonia Guterres. The selected data are gathered from different websites that are specialized in publishing the transcripts o official political speeches.

\section{1- Hillary Clinton (Acceptance speech) 29/7/2016 (American)}

In the spring of 2015, Clinton made her decision to run for the U.S presidency. On 29/7/2016, Clinton voiced this speech accepting the nomination and providing her followers with her upcoming plans to the country. Her speech was chosen for this study analysis as Clinton is regarded to be one of the most influential female politicians worldwide and that the topic of her speech is matching the first theme of analysis in this study.

https://www.politico.com/story/2016/07/full-text-hillary-clintons-dnc-speech$\underline{226410}$

\section{2- Halimah Yacob (Acceptance speech) 13/9/2017(Singaporean)}

Halimah Yacob is the $8^{\text {th }}$ Singaporean president and the first female president in Singapore. On the $13^{\text {th }}$ of September 2017 Halimah voiced this nomination speech to her nation. Halimah was chosen to be the second female in this analysis as it is very rare in the Asian area to find a female politician who have assigned a lot of political positions including a presidency post. Halimah, in this analysis represents the African Islamic female politician who has been nominated as a president to her country.

www.straitstimes.com/politics/halimah-yacob-declared-president-elect-transcriptof-acceptance-speech

\section{3- Michael D Higgins (Inaugural speech) 11/11/2018 (Irish)}

D Higgins is the Irish $9^{\text {th }}$ president from 2011 till the present time. Michael D Higgins is chosen as a male representative in this analysis due to his past work experiences as a university lecturer and a poet. The researcher believes that whoever works in a similar position knows how to master his speech and it is hard to find points of variation in his words. 
Buhuth Journal

Second Issue- part two (2021)

\section{Language \& Literature}

https://www.independent.ie/irish-news/read-michael-d-higgins-inaugurationspeech-in-full-37516720.html

\section{4- Donald Trump (Victory speech) 9/9/2016 (American)}

In 2015 trump announced that he is going to be a candidate in the 2016 U.S presidential election. Trump is known by his tough speeches and by his out of the line speaking behavior. Consequently, the researcher believes that his nomination speech will be a great source for examining a lot of grammatical structures that could help the study i.e. high value modals, pronouns usages, behavioral process..etc.

https://edition.cnn.com/2016/11/09/politics/donald-trump-victoryspeech/index.html

\section{5- Julia Gillard (Misogyny speech) 2012(Australian)}

Julia Gillard was sworn in as the $27^{\text {th }}$ Australian prime minister on the $24^{\text {th }}$ of June 2010 and continued to serve in that post until June 2013. Gillard had a lot of remarkable contributions in the field of women rights in Australia. Gillard is considered to be one of the remarkable Australian who had devoted many of her speeches for women rights. Her Misogyny speech is one of the speeches with high impacts over people tackling women issues. For that reason her speech was chosen to be the first speech regarding the second theme in this analysis.

https://www.smh.com.au/politics/federal/transcript-of-julia-gillards-speech20121010-27c36.html

\section{6-Michelle Obama (on the international women day speech) 8/3/2016(American)}

On January 20, 2009 Barack Obama won the nomination and was elected as the $44^{\text {th }}$ president of the United States of America. In turn Michelle Obama was named the first lady of the United States. Michelle voiced many remarkable speeches in favor of her husband's nomination campaigns. One of her famous speeches was about protecting women from sexual harassment. Michelle was the first U.S lady from 2009 to 2017. During this period of time she focused so much 


\section{Buhuth Journal Language \& Literature}

on social issues such as poverty, healthy living and education. As being a women who studied law and at the same time named the first lady of a leading country like USA, her speech about women rights is regarded as a very important and effective source that could shed a clear light over the grammatical structures of women talking about other women rights and problems.

https://obamawhitehouse.archives.gov/the-press-office/2016/03/08/remarks-firstlady-let-girls-learn-event-celebrating-international

\section{7- Cyril Ramaphosa (on the national women day speech ) 9/8/2019(South African)}

In 2014 Ramaphosa was appointed as the Deputy President of the state by the president Jacob Zuma. In 2018, he was elected as an unopposed president after the resignation of Jacob Zuma. Ramaphose speech on the international women day was chosen for this analysis as he is one of the recent African president who tackled women rights in their speeches that is voiced in English. His speech is very important in reflecting the issues that the African ladies are suffering from.

https://www.gov.za/speeches/president-cyril-ramaphosa-addresses-nationalwomens-day-cele bration-9-aug-8-aug-2019-0000

\section{8- General Antonio Guterres (On Gender Equality) 27/2/2020 (Portuguese)}

António Guterres, the ninth Secretary-General of the United Nations, took office on 1st January 2017. Having witnessed the suffering of the most vulnerable people on earth, in refugee camps and in war zones, the Secretary-General is determined to make human dignity the core of his work, and to serve as a peace broker, a bridge-builder and a promoter of reform and innovation. Guterres speech about gender equality and women issues is chosen in this analysis as being one of the recent speeches voiced in that domain. Moreover, the researcher wanted to make a broader overview of women issues from different multi-nations speakers; that is why Guterres was chosen to represent the Portuguese politicians' views.

https://www.youtube.com/watch?v=zMWL9k3Sjcc 


\section{Language \& Literature}

Those eight speeches were chosen to be the data of this study as they were uttered in the time between 2016 and 2020. The researcher believes that this time interval has encountered so many political events and that the speakers of those speeches are still in political leading positions up till the moment.

\subsection{Procedures of data collection}

\section{The research data are collected in the following procedures:}

1. The two topics of the selected data are the topic of nomination acceptance, and the topic of feminine issues and women roles in societies.

2. The researcher searched for political leaders tackling those predetermined topics.

3. The study started by getting frequencies for the most and the least grammatical linguistic items then moved to show the significance of those frequencies.

4. The study gives data analysis on both a quantitative and qualitative level and in the light of the theoretical framework of the study and with the help of the corpus software.

5. The researcher signed for a free trial at Sketch Engine online corpus software.

6. The speeches are compiled in eight files via sketch engine; each theme is represented with four files one for each speaker.

7. The analysis started by getting the most and the least frequent verbs then moved to show the significance of such frequencies.

8. The data are analyzed on both a quantitative and qualitative level and in the light of the theoretical framework of the study and with the help of the corpus software.

\section{V- Data Analysis}

\subsection{The theme of victory and nomination acceptance corpus analysis}

In this scope, the speeches of Hillary Clinton (29/7/2016) and Halimah Yacob (13/9/2017) represent the female's voice, while the speeches of Michael D Higgins 
Buhuth Journal

Second Issue- part two (2021)

\section{Language \& Literature}

$(11 / 11 / 2018)$ and Donald Trump (9/9/2016) are that of male's voice. The following tables show the number of tokens, words, sentences, and documents for each gender.

Table.1 Females Accepting Nomination

\begin{tabular}{|lllll|}
\hline & Tokens & Words & Sentences & Documents \\
\hline Clinton & 6,355 & 5,451 & 411 & 1 \\
\hline Yacob & 1,074 & 938 & 65 & 1 \\
\hline Total & 7,429 & 6,389 & 476 & 2 \\
\hline
\end{tabular}

Table.2 Males Accepting Nomination

\begin{tabular}{|lllll|} 
& Tokens & Words & Sentences & Documents \\
\hline Trump & 1,929 & 1,613 & 166 & 1 \\
\hline D Higgin & 3254 & 2,915 & 99 & 1 \\
\hline Total & 5,183 & 4,528 & 265 & 2 \\
\hline
\end{tabular}

5.2 The theme of Women rights and feminine issues in society corpus analysis

In this scope the speech of Julia Gillard, the $27^{\text {th }}$ prime minister of Australia entitled Misogyny speech (9/10/2012) and the speech of Michelle Obama on the international women day (8/3/2016) represent the female voice. While the speech of Cyril Ramaphosa, the South African president on the national women day (9/8/2019) and the speech of Antonio Guterres, the Portuguese politician about gender equality (9/3/2020) represent the male voice. The following tables show the number of tokens, words, sentences, and documents for each gender. 
Buhuth Journal

Second Issue- part two (2021)

\section{Language \& Literature}

Table. 3 the speeches of female politicians concerning women's rights

\begin{tabular}{|lllll|} 
& Tokens & Words & Sentences & Documents \\
\hline Gillard & 2,531 & 2,262 & 94 & 1 \\
\hline Obama & 2967 & 2559 & 138 & 1 \\
\hline Total & 5,498 & 4,821 & 232 & 2 \\
\hline
\end{tabular}

Table.4 the speeches of male politicians concerning women's rights

\begin{tabular}{|lllll|} 
& Tokens & Words & Sentences & Documents \\
\hline Ramaphosa & 2,831 & 2,536 & 116 & 1 \\
\hline Guterres & 1,067 & 935 & 58 & 1 \\
\hline Total & 3,898 & 3,471 & 174 & 2 \\
\hline
\end{tabular}

\section{3-Transitivity analysis in theme I and II:}

\subsubsection{A- Transitivity in females' theme I and theme II:}

Transitivity is a system for explaining the whole clause instead of describing the verb and its object (Thompson, 1996, p. 78). The following table shows transitivity in females accepting nomination speeches and the frequency of each type of process. The six processes are sorted from the most to the least frequently used.

\section{A- Theme I "nomination acceptance":}

The following table shows the number of verbs found in each female speech in theme I. Both Hillary Clinton and Halimah Yacoub used different verbs in their speeches in theme I. 


\section{Language \& Literature}

Table 5. Verbs in each female speaker speech theme I

\begin{tabular}{|r|r|}
\hline Hillary Clinton & Halimah Yacoub \\
\hline 259 different verb and 1,077 & 69 different verb and 178 \\
occurrence & occurrence \\
\hline
\end{tabular}

Table 6. Females' transitivity theme I

\begin{tabular}{|c|c|c|c|}
\hline Process Type & Process verb & Number & Percentage \\
\hline $\begin{array}{l}\text { Material } \\
\text { Process }\end{array}$ & $\begin{array}{l}\text { Do, put, work, go, come, } \\
\text { build, fight, write, give, } \\
\text { pay, bring }\end{array}$ & 580 & $46.2 \%$ \\
\hline $\begin{array}{l}\text { Relational } \\
\text { Process }\end{array}$ & Be, have, become & 354 & $28.2 \%$ \\
\hline $\begin{array}{l}\text { Behavioral } \\
\text { Process }\end{array}$ & $\begin{array}{l}\text { become, face, support } \\
\text { let, want, need }\end{array}$ & 142 & $11.3 \%$ \\
\hline $\begin{array}{l}\text { Mental } \\
\text { Process }\end{array}$ & $\begin{array}{l}\text { Believe, know, hear, mean, } \\
\text { think, deserve, see }\end{array}$ & 123 & $9.8 \%$ \\
\hline $\begin{array}{l}\text { Verbal } \\
\text { Process }\end{array}$ & Say, tell, thank, ask, talk & 45 & $3.5 \%$ \\
\hline $\begin{array}{l}\text { Existential } \\
\text { Process }\end{array}$ & There (be) & 11 & $0.8 \%$ \\
\hline Total & 1255 & & $100 \%$ \\
\hline
\end{tabular}




\section{Language \& Literature}

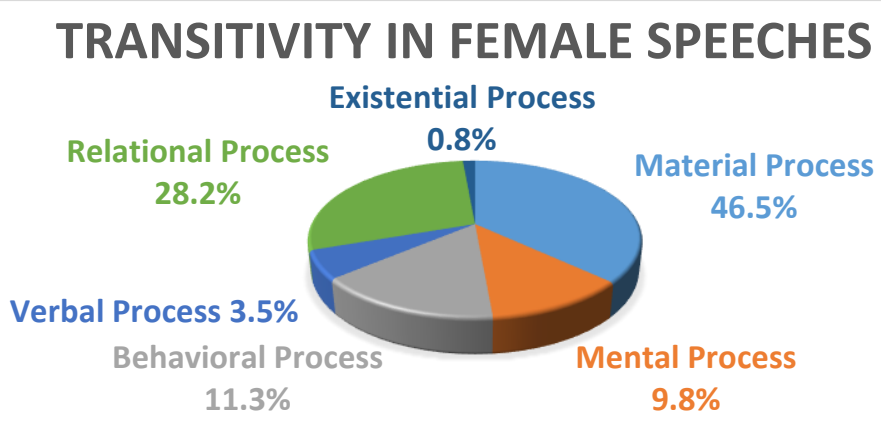

Figure 1. Transitivity system in females' theme I

A total of 1255 clauses are found in female speeches in theme I and all the six process types occurred in those speeches. As clear in the previous table and figure the material process is the highest of all with $46.2 \%$ followed by the relational process with $28.2 \%$ followed by the behavioral with $11.3 \%$ which in its turn followed by the mental process that occurred with $9.8 \%$ percentage. Finally, comes the verbal with $3.5 \%$ followed by the existential process with $0.8 \%$ percentage.

\section{I- Material Process Examples}

1) We (Actor) will work (Material) with all Americans and our allies to fight (Material) terrorism (Goal).

2) I (Actor) went (Material) to work (Material) for the Children's Defense Fund (Goal).

3) That's what made (Material) it possible to stand up (Material) to a King (Goal).

4) My friends, we (Actor)'ve come (Material) to Philadelphia (Goal) -- the birthplace of our nation -- because what happened in this city 240 years ago still has something to teach us today.

5) We (Actor) will not build (Material) a wall (Goal).

6) Our Founders (Actor) fought (Material) a revolution (Goal) and wrote (Material) a Constitution (Goal) so America would never be a nation where one person had all the power. 


\section{Language \& Literature}

\section{II- Relational Process Examples}

1) We (possessor) have (possessive) both internal challenges and external challenges (Possessed) that we need to overcome.

2) Everyone (Possessor) has (possessive) a chance (Possessed) to reach the highest office of the land.

3) Your cause (token) is (identifying) our cause (value).

4) I (Carrier)'m (Attributive) really very grateful (Attribute) to you because you've taken time off from your work and really made the effort to come here all the way.

5) I (Carrier) am (Attributive) not a reserved president (attribute).

6) We (carrier) are (attributive) Singaporeans (attribute), we (carrier) are (attributive) in a country (attribute) that we (carrier) are (attributive) really proud of (attribute).

\section{III-Behavioral Process Examples}

According to Halliday (1994), behavioral clauses are "processes of (typically human) physiological and psychological behavior, like breathing, coughing, smiling, dreaming and staring" (p. 139). In this process, there is only one participant, namely behaver (the agent who behaves).

1) The choice we (behaver) face (behavioral) is just as stark when it comes to our national security.

2) I (behaver) look forward (behavioral) to working very closely with you and I (behaver) believe (behavioral) we can do good together and I (behaver) invite (behavioral) you to do good together with me.

3) He (behaver) loses (behavioral) his cool at the slightest provocation.

4) I (behaver) really feel (behavioral) very appreciated and I am deeply grateful to all of you for your presence here today.

5) We (behaver) should support (behavioral) our steelworkers and autoworkers and homegrown manufacturers. 
Buhuth Journal

Second Issue- part two (2021)

\section{Language \& Literature}

\section{IV- Mental Process Examples}

1) I (senser) know (mental) that some have some doubts of the reserved election (phenomenon).

2) We are not just chanting slogans again, but we (senser) really mean (mental) it.

3) Entrepreneurs (senser) who see (mental) possibilities in every problem.

4) We (senser) heard (mental) the man from Hope, Bill Clinton.

5) I (senser) was still thinking (mental) of Lauren, Debbie and all the others ten years later in the White House Situation Room when President Obama made the courageous decision that finally brought Osama bin Laden to justice.

\section{V- Verbal process Examples}

1) Many of you (sayer) not only gave (Verbal) words of encouragement and support (verbiage), many of you came to pat me on the back. Many of you also hugged me. And many of you (sayer) told (verbal) me that you would support me even without my asking or saying anything (verbiage).

2) I (sayer) ask (verbal) you now, dear Singaporeans that the election is over, to stand together (verbiage) so we can focus on our core priorities to ensure that Singapore remains a great home for everyone.

3) He (sayer) also talks (verbal) a big game about putting America First (verbiage).

4) Donald Trump (sayer) says (verbal) he wants to make America great again (verbiage); well, he could start by actually making things in America again.

\section{VI- Existential Process Examples}

1) Although there is no election, my commitment to serve you remains the same

2) There is no diminution even one bit of my desire to serve you.

3) There are no guarantees.

4) There is no other Donald Trump. 


\section{Buhuth Journal Language \& Literature}

The material process is the process of doing or performing an action. This shows that females tend to be active politicians; they are part of most of the actions represented by those material processes. Most of those material processes of females include the two participants i.e. the actor and the goal. It has been found that also the majority of those material processes are made by an actor referring to or including the female speaker. This means that female politicians are active members of the community; they are part of every action being performed. Goal in their speeches represents their upcoming plans and goals as clear in the previous examples.

Females' relational processes are widely used to express the political status of their country and also to show what privileges they do have. This high percentage reveals how realistic they are. They tend to talk about current status and possessions from the very beginning i.e. in their acceptance speeches. There are three types of relational process; attributive, identifying and possessive. The three of them were found in female speeches. Examples $1 \& 2$ represent the possessive while 3 represents the identifying and finally $4,5 \& 6$ represent the attributive.

The researcher has found that the majority of the behavioral processes found in female speeches tend to have females as the behaver of the action. This finding shows that females are good speakers about their behaviors. Both Halimah and Clinton feel proud talking about themselves and their actions. It is also found when females talk about their own behaviors, they use behavioral verbs that reflect positivity and strength such a face, look forward, believe support. While those verbs of negative meanings are behaved by other entities as in example 3 .

Politics is a game of minds and mental process is the process of cognition. For that reason, the mental process is of great importance. Females showed an efficient usage of cognition transmission through their acceptance speeches. They pretty know that in order to gain influences they should speak to minds. This is obviously seen in the above examples. From the data, it can be noted that the sensers of the mental processes are mostly $\mathbf{I}$ or we. The use of $\mathbf{I}$ shows that the speaker is quite 


\section{Language \& Literature}

determined to carry out the new policies. And the usage of the plural first person pronouns shows that females want to indulge their citizens in their political game. The material processes are subcategorized into four types which are cognition, affection, perception and volition. Females effectively used a variety of those four types. They used the verbs "believe" (22) times, "know" (21) times, "mean" (8) times and "think" (7) times to represent cognition. While they used verbs like "want" (17) times and "need" (8) times to represent volition. Females also showed affection through using verbs like "see" (14) times, "hear" (14) times and "feel" (5) times. Finally, the verb "like" was mentioned in their compiled speeches (4) times to represent affection.

The verbal process does not show high frequency in female speeches. The last process and the least used by females was the existential process. This process marks the existence or inexistence of something. The researcher found that most of the existential processes used by females are in the negation form. This means that females used a technique of assurance through negation.

\section{B- Theme II "feminine issues and women's role in societies"}

The following table shows the number of verbs found in each female speech in theme II. Both Julia Gillard and Michelle Obama use different verbs in their speeches in theme II.

Table 7.Verbs in each female speaker speech theme II

\begin{tabular}{|r|r|}
\hline Julia Gillard & Michelle Obama \\
\hline 111 different verb and 399 & 150 different verb and 464 \\
occurrence & occurrence \\
\hline
\end{tabular}

Julia Gillard used in her Misogyny speech about 111 different verb with a 399 occurrence and Michelle Obama used about 150 different verb with a 464 occurrence. The difference between the two ladies is not highly significant. It 


\section{Language \& Literature}

seems that the two females' politicians are advocating women's rights in the same way. Their sense of feminism seems to be nearly equal.

The following table shows transitivity in the two female speeches and the frequency of each type of process. The six processes are sorted from the most to the least frequently used.

Table 8. Transitivity in females' theme II

\begin{tabular}{|c|c|c|c|}
\hline Process Type & Process verb & Number & Percentage \\
\hline Relational Process & Be, Have & 274 & $31.7 \%$ \\
\hline Material Process & $\begin{array}{l}\text { Make, Do, work, Put, Give, } \\
\text { Come, Uplift, Damage...etc. }\end{array}$ & 272 & $31.5 \%$ \\
\hline Mental Process & $\begin{array}{l}\text { See, Want, Realize, } \\
\text { Need....etc. }\end{array}$ & 140 & $16.2 \%$ \\
\hline Behavioral Process & $\begin{array}{l}\text { Support, Enjoy, Bear, Share, } \\
\text { Lead....etc. }\end{array}$ & 113 & $13 \%$ \\
\hline Verbal Process & $\begin{array}{l}\text { Speak, Talk, Thank, } \\
\text { Apologies, Describe } \ldots . . \text { etc. }\end{array}$ & 56 & $6.4 \%$ \\
\hline Existential Process & There (be) & 8 & $0.9 \%$ \\
\hline Total & 863 & & $100 \%$ \\
\hline
\end{tabular}




\section{Language \& Literature}

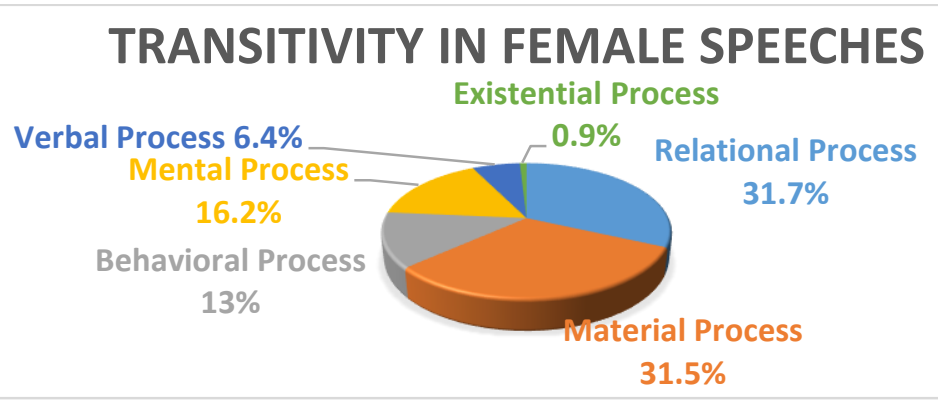

Figure 2. Females' transitivity theme II

A total of 863 clauses are found in female speeches in theme number II and all the six process types occurred in those speeches. As shown in the previous table and figure the relational process is the highest of all with $31.7 \%$ percentage followed by the material process with $31.5 \%$ percentage followed by the mental process with $16.2 \%$ percentage which in its turn followed by the behavioral process that occurred with $13 \%$ percentage. Finally, occurs the verbal process with $6.4 \%$ percentage followed by the existential process with $0.9 \%$.

\section{I- Examples of the relational process:}

1) He's certainly in a position to speak more intimately about Mr. Slipper than I am.

2) I (Token) 'm (Identifying) so proud (Value) that you all are here.

3) The President and I (Token), (Possessor) are (Identifying) very lucky (Value) to have (Possessive) her (Possessed) as a friend.

4) Every single one of us (Possessor) has (Possessive) a role to play (Possessed) on this issue.

\section{II- Material Process Examples:}

1) Their minds (Actor) do (Material) not really matter.

2) It is so easy to take for granted all the progress we (Actor)'ve made (Material) on these kinds of issues (Goal).

3) Nobody (Actor) walked (Material) out of the room (circumstance); no-one (Actor) walked (Material) up to Mr. Jones (circumstance) and said that this was not acceptable. 


\section{Language \& Literature}

\section{III-Mental Process Examples:}

1) He (Senser) wants (Mental) to know what misogyny looks like in modern Australia.

2) I (Senser) have seen (Mental) the press reports of those text messages.

3) You see, they (Senser) know (Mental) that education is their only path to self-sufficiency.

4) Because if he (Senser) wants (Mental) to know what misogyny looks like in modern Australia, he (Senser) doesn't need (Mental) a motion in the House of Representatives, he (Senser) needs (Mental) a mirror.

\section{IV-Behavioral Process Examples:}

1) When Nourhan got accepted to a girls' science and technology boarding school (Behaver) supported (Behavioral) by USAID, of course she was hesitant to leave home.

2) Some of you are students (Behaver) who will be leading (Behavioral) the way on this issue in years to come.

3) I know that each of us here today has a story like Samantha (Behaver) shared (Behavioral) about how we first got engaged in this issue.

\section{V- Verbal process Examples:}

1) He (Sayer)'s certainly in a position to speak (Verbal) more intimately about Mr. Slipper (Verbiage) than I am, and many other people in this Parliament, given this long personal association.

2) Thank (Verbiage) you all so much.

3) $\mathrm{He}$ (Sayer) could apologize (Verbal) for all his past statements (circumstance), he (Sayer) could apologies (Verbal) for standing next to signs describing me as a witch and a bitch (Verbiage), terminology that is now objected to by the frontbench of the Opposition.

\section{VI-Existential process Examples:}

1) But now, there's an assumption that this is a bad thing. 


\section{Buhuth Journal Language \& Literature}

Second Issue- part two (2021)

2) Oh dear, there's this thing called sexism, oh my lords, there's this thing called misogyny.

There is a clear difference between female speeches in theme I and theme II. In theme I females used the material process in the highest rank to reflect their active plans in ruling and governing. However in theme II the relational process has the highest frequency; this is to show that they are tackling a serious real topic which is the feminine issues in societies. The relational process is the process of reality; hence it is used with the highest frequency of all the six processes to show that real life topic of women. Females in the second theme still give priority to the material process. They still want to do effort and make actions towards their feminine issues and problems. They were very active in theme I in presenting their future plans and continued to be active in theme II also. Most of those material processes used in theme II contain actors and goals. It has been noticed that the actors used in their material verbs tend to be a third person entity who might be the responsible for their issues and problems. Mental process in theme II showed a higher importance than theme I as females used the mental verbs with a higher percentage that reached $16.2 \%$. This may show the importance of the topic they are tackling in theme II. Again in theme II, females used the four categories of the mental process. Cognition is represented via verbs like believe which was used (4 times), know which was used (11 times), understand which was used (3 times), learn which was used (5 times) and realize which was used (2 times). Moreover, perception was also shown through verbs like see which was used about (20 times), hear which was used about (4 times) and feel which was used about (4 times). Meanwhile, volition was indicated via verbs like want (12 times), need (4 times) and hope (2 times). Like theme I, theme II also shows that most of the behavioral processes include a female(s) as a behaver of the action. This again assures the assumption that females are good speakers about their behaviors and human actions. However, a clear difference was found as in theme I females' used behavioral verbs that reflect their feminine soft nature whereas in theme II most of their behavioral processes were meant to show power and strength. Females' behavioral processes in that domain tend to be similar to that used by their counter 


\section{Language \& Literature}

gender. No big difference was noticed in females' usages to the verbal processes in the two themes. As in theme I, theme II also shows that the verbal verbs were of a least priority. The last process and the least used by females was the existential process. This process marks the existence or inexistence of something. A clear difference was found in females' usages to the existential processes between theme I and theme II. In theme I, females tended to use most of their existential process in the negative form seeking assurance. However, in theme II, all the existential processes were in the affirmative form. This difference might show that they are so serious in tackling their feminine issues and that they used all of the affirmative forms to reflect the fact of women suffering in societies.

\subsubsection{B- Transitivity in males' theme I and theme II:}

\section{A- Theme I "nomination acceptance"}

The following table shows the number of verbs found in the speech of each male speaker in theme I. Both Donald Trump and Michael D Higgins used different verbs in their speeches in theme I.

Table 9. Verbs in each female speaker speech theme I

\begin{tabular}{|r|r|}
\hline Donald Trump & Michael D Higgins \\
\hline 72 different verb and 320 & 170 different verb and 462 \\
occurrence & occurrence \\
\hline
\end{tabular}

The following table shows transitivity in males accepting nomination speeches and the frequency of each type of process. The six processes are sorted from the most to the least frequently used. 
Buhuth Journal

Second Issue- part two (2021)

\section{Language \& Literature}

Table 10. Males' transitivity in theme I

\begin{tabular}{|c|c|c|c|}
\hline Process Type & Process verb & Number & $\begin{array}{l}\text { Percenta } \\
\text { ge }\end{array}$ \\
\hline $\begin{array}{l}\text { Relational } \\
\text { Process }\end{array}$ & Be, have, become & 310 & $39.6 \%$ \\
\hline Material Process & $\begin{array}{l}\text { Do, put, work, go, come, } \\
\text { bring, make, take }\end{array}$ & 240 & $30.6 \%$ \\
\hline Verbal Process & Say, tell, thank, call, speak & 88 & $11.2 \%$ \\
\hline $\begin{array}{l}\text { Behavioral } \\
\text { Process }\end{array}$ & $\begin{array}{l}\text { Require, support, share, get, } \\
\text { let, live }\end{array}$ & 76 & $9.7 \%$ \\
\hline Mental Process & $\begin{array}{l}\text { Want, know, see, recognize, } \\
\text { look }\end{array}$ & 59 & $7.5 \%$ \\
\hline $\begin{array}{l}\text { Existential } \\
\text { Process }\end{array}$ & There (be) & 9 & $1.1 \%$ \\
\hline Total & 782 & & $100 \%$ \\
\hline
\end{tabular}

\section{TRANSITIVITY IN MALE SPEECHES THEME I Existential Process}

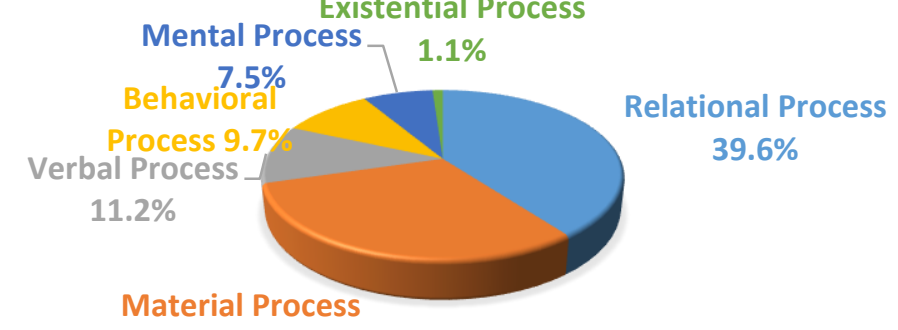

$30.6 \%$

Figure 3. Males' transitivity in theme I 


\section{Buhuth Journal Language \& Literature}

A total of 782 clauses is found in male speeches in theme number I and all the six process types occurred in those speeches. As shown in the previous table and figure, the relational process is the highest of all with $39.6 \%$ percentage followed by the material process with $30.6 \%$ percentage followed by the verbal with an $11.2 \%$ percentage which in its turn followed by the behavioral process that occurred with a $9.7 \%$ percentage. Finally, comes the mental with $7.5 \%$ percentage followed by the existential with $1.1 \%$ percentage.

\section{I- Relational Processes examples:}

1) Our veterans (carrier) are (attributive) incredible people (attribute).

2) No dream (carrier) is (attributive) too big (attribute), no challenge (carrier) is (attributive) too great (attribute).

3) This political stuff (token) is (attributive) nasty (attribute), and it (token) is (identifying) tough (attribute).

4) He (Token) was (identifying) one of the folks that was negotiating to go against those Democrats (value).

5) Every single American (possessor) will have (possessive) the opportunity (possessed) to realize his or her fullest potential.

6) We (possessor) have (possessive) a great economic plan (possessed).

Relational process is the process of being and it aims to describe the attribute of something or to identify something. Male politicians used the attributive relational examples to describe the situation of the time, the economy and the actions that the new politician is going to use to gain more support from the audiences. Male representatives not only used the attributive relational processes but also used the identifying one to explain and identify to their followers their upcoming plans and intentions. Beside the previous two relational types, they also used the possessive relational process that aims at arising the sense of belongingness to their country and to the new upcoming regime.

\section{II- Material Processes examples:}

1) $\mathrm{He}$ (Actor) traveled (Material) with us and he (Actor) went (Material) through meetings, and Rudy never changes. 


\section{Language \& Literature}

2) I (Actor) 'm reaching out (material) to you for your guidance and your help so that we (Actor) can work (Material) together and unify (Material) our great country (Goal).

3) We (Actor)'re going to rebuild (Material) our infrastructure (Goal), which will become, by the way, second to none.

4) We (Actor) will also finally take care (Material) of our great veterans (Goal) who have been so loyal, and I've gotten to know so many over this 18-month journey.

5) As we (Actor) come together (Material) for these tasks (Goal) of addressing the what and how of what is to be remembered, let us recognize that what is involved is much more than the fixing of a story, or the reconciliation of competing versions or struggles to colonize collective memory.

\section{III-Verbal Processes examples:}

1) You know, they (Sayer) kept saying (Verbal)we have a small staff (Verbiage).

2) Ideas matter and history (Sayer) tells (Verbal) us that anti-intellectualism has been, and remains, the weapon of authoritarian and anti-democratic forces in so many parts of our shared, vulnerable planet (Verbiage).

3) It is about how we engage and interact with each other, how we (Sayer) speak (Verbal) to each other in a way that is that is open yet respectful of difference.

4) They (Sayer) have rejected the undermining of democracy by xenophobia and hate in so many places and have replied (Verbal) by calling for the wider and deeper democracy (Verbiage), to which I have referred, for a real freedom that is inclusive.

\section{IV- Behavioral processes examples:}

1) That requires (behavioral) a rigorous commitment to removing the many barriers to participation; recognizing, strengthening and supporting the momentum and demand for equality, positive transformation and 
sustainability, a momentum that is already underway in so many of our communities.

2) I will, I (behaver) have emphasized (behavioral), be a President for all of the Irish people, wherever they may be and in whatever circumstances, those (behaver) who supported (behavioral) me and those who were not among that number.

3) Those decencies (behaver) are the ones that urge (behavioral) us to spring to respond to each other's vulnerabilities, to see the merit of enhancing each other's capacities, of encountering and sharing care and love, of working together for common benefit in a public world that we (behaver) share (behavioral).

4) I promise you that I (behaver) will not let (behavioral) you down.

\section{V- Mental processes examples:}

1) That is now what (phenomenon) I (senser) want (mental) to do for our country.

2) First, I (senser) want (mental) to thank my parents (phenomenon), who I know are looking down on me right now.

3) They (senser) see (mental) a future (phenomenon) as defined by ethics, philosophy and creativity as the kind of future to which science and technology should be called to assist.

4) I (senser)'ve spent my entire life in business, looking (mental) at the untapped potential in projects and in people all over the world (phenomenon).

5) I would like to take this moment to thank some of the people who really helped me with this.

\section{VI- Existential process examples:}

1) There is a commitment to equality, to strong sustainable communities, to the sharing of history and to shaping of the future together; recognizing our 


\section{Buhuth Journal Language \& Literature}

vulnerabilities, drawing on and enhancing our individual and collective capacities.

2) There are some contemporary cultural influences that may be dismissive of any responsibility towards the needs, opinions or experience of others, and there can, in too many parts of our shared discourse be too much emphasis on division and domination rather than reflection or understanding.

3) There must be a consideration as to their adequacy and appropriateness for new circumstances, new dreams and new concerns.

Males' relational process came with $39.6 \%$ while, female speeches offered about $28.8 \%$ relational verbs. Unlike females, males' politicians used the three types of the relational processes in an equal frequency differing from females who devoted much focus on both the possessive and attribute relational processes and give a least focus on the identifying one. Unlike females, male speakers gave the material processes a second priority. This result may show that females are active, enthusiastic leaders more than their counterpart. Moreover, the choice of how strong and powerful the material verbs of the female speeches represent, shows another difference between the two genders. Hillary and Halimah used material verbs such as work, made, stand up, build and fought. While the choices of their counter gender were less active such as take care, come together, reach out and unify. Verbal processes show a higher importance in male speeches; they used about $11.2 \%$ verbal verbs. Males used that kind of transitivity processes in the third rank, which openly shows that they care more about verbal communication more than their counter gender. Males' speeches show a wider awareness of the effect of verbal processes in establishing a strong bonded relationship with audience. Unlike the behavioral processes used by females' speakers, males' behavioral processes tend to show that the majority of behavers are some other people rather than the speakers themselves. Another core difference between both genders is that the meaning of the behavioral verbs used by males tends to reflect a meaning of strength like (support), (emphasize) and (urge) while that used by females tends to reflect their soft nature as clear in (look forward), (believe), (feel) and (support). 


\section{Language \& Literature}

The analysis of the data based on statistics shows that males' speakers are good users for the material processes although they are not that much professional and multifarious like females. Males had used all the four types of the mental processes. As evident in verbs such as (want) which was mentioned (15) times in their speeches to represent the volition. Also, their usage of verbs like (know) and (recognize) which were mentioned (9) and (5) times in their compiled texts; (know) and (recognize) represent the cognition. Affection is also clear in their speeches through their usage to verbs such as (like) that was mentioned only (1) time. Finally, the perception type comes which is also present in males' speeches in verbs such as (see) and (look) which were mentioned (5) and (7) times. Similar to the speeches of female politicians, the speeches of male politicians reflect that the existential process is the least used process. However, unlike females, males used all their existential processes in the affirmative form i.e. their tool of assurance was through affirmativeness and not negation.

\section{B-Theme II "feminine issues and women's role in societies"}

The following table shows the number of verbs found in the speeches of each male politician in theme II. Both Cyril Ramaphosa and Antonio Guterres used different verbs in their speeches in theme II.

Table 11. Verbs in each female speaker speech theme I

\begin{tabular}{|r|r|}
\hline Cyril Ramaphosa & Antonio Guterres \\
\hline 161 different verb and 393 & 83 different verb and 155 \\
occurrence & occurrence \\
\hline
\end{tabular}

A huge difference is depicted between the two male speakers. Ramaphosa used 161 different verbs with a 393 instances while Guterres used 83 different verb with 155 instances. This may portrait Ramaphosa as being more into feminism and its issues that Guterres. 


\section{Language \& Literature}

The following table shows transitivity in males tackling feminine issues speeches and the frequency of each type of process. The six processes are sorted from the most to the least frequently used.

Table. 12. Males transitivity in theme II

\begin{tabular}{|c|c|c|c|}
\hline Process Type & Process verb & Number & Percentage \\
\hline $\begin{array}{l}\text { Relational } \\
\text { Process }\end{array}$ & Be, have, become & 180 & $32.8 \%$ \\
\hline Material Process & Make, Do, Work, Take...etc. & 108 & $19.7 \%$ \\
\hline $\begin{array}{l}\text { Behavioral } \\
\text { Process }\end{array}$ & $\begin{array}{l}\text { Let, Achieve, Improve, Care, } \\
\text { Help,....etc. }\end{array}$ & 95 & $17.3 \%$ \\
\hline Mental Process & $\begin{array}{l}\text { Ensure, See, Want, Realize, } \\
\text {...etc. }\end{array}$ & 80 & $14.5 \%$ \\
\hline Verbal Process & $\begin{array}{l}\text { Thank, Call, Salute, Tell, } \\
\text { Describe,...etc }\end{array}$ & 77 & $14 \%$ \\
\hline $\begin{array}{l}\text { Existential } \\
\text { Process }\end{array}$ & There (be) & 8 & $1.4 \%$ \\
\hline Total & 548 & & $100 \%$ \\
\hline
\end{tabular}

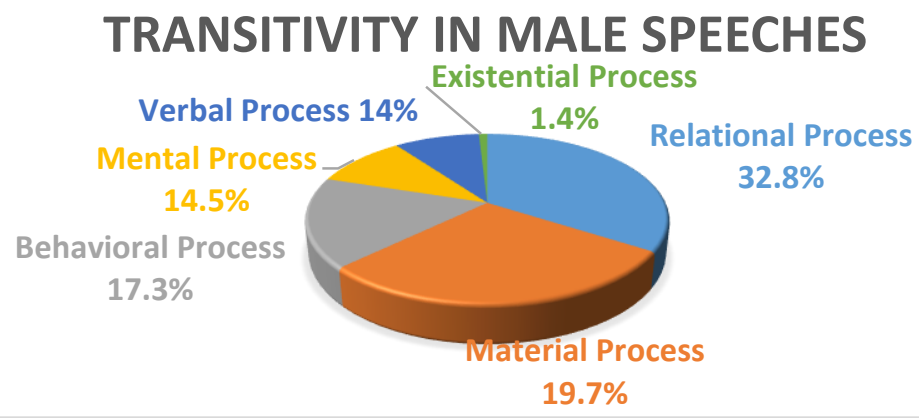

Figure 5. Transitivity in males' theme II 


\section{Language \& Literature}

A total of 877 clauses are found in male speeches in the second theme and all the six process types occurred in those speeches. As shown in the previous table and figure the relational process is the highest of all with a $34 \%$ percentage followed by the material process with $28.7 \%$ percentage followed by the behavioral with a $17.1 \%$ percentage which in its turn followed by the mental process that occurred with a $10 \%$ percentage. Finally, comes the verbal with $9.1 \%$ percentage followed by the existential with $0.9 \%$ percentage.

\section{I- Relational process examples:}

1) It is a great pleasure to be here today.

2) That is gender inequality and discrimination against women and girls.

3) Women have a higher fatality rate from heart attacks because diagnostic tools are designed around default man.

4) Men have a gender too.

\section{II-Material process examples:}

1) We have made a number of advances.

2) Drought and famine mean women work harder to find food and water, while heat waves, storms and floods kill more women and girls than men and boys.

3) We are taking measures to restore our economy and create economic opportunities, especially for women and youth.

\section{III- Behavioral process examples:}

1) Let us support great initiatives like \#TheBestManCanBe, a male mentorship program being run by the creators of the Gogo Nozizwe commercial.

2) As sexual partners, let us care enough for each other to practice safe sex.

3) We signed a Presidential Health Compact with stakeholders across the health sector on a series of measures to significantly improve the quality of the health care our people receive.

\section{IV-Mental process examples:}


1) Today, as Secretary-General of the United Nations, I see one overwhelming injustice across the globe

2) There is a South Africa we want.

3) He did this because he knew that access to quality health care is fundamental to improving the lives of women.

\section{V- Examples of the Verbal process:}

1) They are calling for freedom from violence, greater representation and urgent climate action

2) I salute those who have courageously spoken up and fought back.

VI- Existential process examples:

1) There is a strong and relentless pushback against women's rights.

2) There are deficiencies in our laws.

There is a remarkable difference between theme I and theme II in terms of male politicians' usage to the relational process. In theme I they used the process of reality with a very high frequency which was $44.8 \%$. This fact shows that they are voicing their nomination speeches with real promises and plans. However, when it came to talking about women and feminine issues in societies as in theme II, the researcher has found a remarkable decrease in using such process. Relational process was used in theme II with a $32.8 \%$. This may indicate a less concern towards the topic being tackled. A noticeable mount in the percentage of the material processes used by male speakers has been found. In theme I, males used about $15.8 \%$ while, in theme II, the percentage mount to be $32.8 \%$. This may show their potential energy in solving the problem. Another noticeable difference was found between females' and males' usage of the material processes in theme II. Actors in females' speeches represent unknown entities; however in male speeches, actors are known and males are involved which is clear from using the pronoun (We). The percentage of males' speakers using the behavioral process has mounted. In theme I they used behavioral processes with a $13.3 \%$, while in theme II the percentage has increased to be $17.3 \%$.This finding may show that males tend to act humanly towards that feminine issues. Their behavioral choices in theme II are of more tender such as (Support, Care \& Improve). Males also made another 


\section{Buhuth Journal \\ Language \& Literature}

Second Issue- part two (2021)

difference in using the behavioral processes. In theme II, males tended to be the behavers of most of the used processes unlike what is done by females. Male politicians used the mental process in theme II with $14.5 \%$ and with only $9.5 \%$ in theme I. This shows that male speakers are more realistic in dealing with female issues. In the two themes males and females used the four types of the mental process. The verbal process also does not show a huge difference. As in theme I, males used about $13.8 \%$ of their verbal actions and $14 \%$ in theme II. No big difference was proved in males' usage of the existential processes in both themes I and II. Males did not change their way of assurance through affirmativeness in both themes.

Table 13. The overall transitivity frequencies in theme I \& II

\begin{tabular}{|r|r|r|r|r|}
\hline \multirow{2}{*}{$\begin{array}{c}\text { Process } \\
\text { Type }\end{array}$} & \multicolumn{2}{|c|}{ Theme I } & \multicolumn{2}{c|}{ Theme II } \\
\cline { 2 - 5 } & Female & Male & Female & Male \\
\hline Relational & $28.2 \%$ & $44.8 \%$ & $39.6 \%$ & $32.8 \%$ \\
\hline Material & $46.2 \%$ & $15.9 \%$ & $30.6 \%$ & $19.7 \%$ \\
\hline Mental & $9.8 \%$ & $9.7 \%$ & $7.5 \%$ & $14.5 \%$ \\
\hline Behavioral & $28.2 \%$ & $13.3 \%$ & $9.7 \%$ & $17.3 \%$ \\
\hline Verbal & $3.5 \%$ & $13.8 \%$ & $11.2 \%$ & $14 \%$ \\
\hline Existential & $0.8 \%$ & $2.1 \%$ & $1.1 \%$ & $1.4 \%$ \\
\hline
\end{tabular}

The overall transitivity analysis showed that both genders used the six types of processes in both of the two themes. Male speakers are more into realistic than females, this is clear from their relational process percentage in theme I. In theme I, males used about $44.8 \%$ while females used $28.2 \%$ relational process. In theme II, females used higher frequency to show their realistic attitude towards the topic of speaking as they used about 39.6\% relational process while males used about $32.8 \%$. Material process was also another area that highlighted the gender variation theme in this study. Females used about $46.2 \%$ material process in theme I, while males used only $15.9 \%$. In theme II, females used about $30.6 \%$ while the other 


\section{Buhuth Journal Language \& Literature}

gender used $19.7 \%$. This finding shows females to be more active and enthusiastic than their counterpart. In theme I, males and females used the four types of the mental process with nearly equal percentages which in turn does not give much evidence about the gender variation aspect. However, in theme II male speakers turned to be the highest with a $14.5 \%$ while, females used only $7.5 \%$ mental verbs. This in turn can give an indication on how the topic of speaking has a role in displaying the gender differences. The behavioral process showed a gender difference that is based on the topic of speech. This is clear from the results that showed females using about $22.2 \%$ behavioral process in theme I and about $13.3 \%$ in theme II, while males used about $9.7 \%$ in theme I and $17.3 \%$ in theme II. Those percentages showed females to be the highest behavioral process users in theme I and males to be the highest in theme II. Comparing the two genders in dealing with the verbal processes it was found that males give a wider focus to their oral production through using the verbal processes more than their counter gender. Males used about $13.8 \%$ in theme I, and about $14 \%$ in theme II, while, females used about $3.5 \%$ in theme I, and $11.2 \%$ in theme II. It is also clear that both female and male politicians gave a least priority to the existential process which was used in the last rank of all the other six processes by both genders in the two themes. This indicates that the two genders do not only focus on the existence of the feminine issues but rather give attention on how to solve them.

\section{VI-Findings and Conclusion}

This chapter presents the conclusion of the study based on the analysis and discussion of the data which carried out in section five. After analyzing the data quantitatively and qualitatively following Halliday's Transitivity system and using Sketch engine online software to get statistical results, the researcher concluded the following:

Transitivity in males' and females' speeches was a great area that helped to prove the gender variation. However, the differences in the topic of speeches govern this. The change of the topic of speeches showed a difference within the 


\section{Buhuth Journal Language \& Literature}

same gender speeches and also showed another difference between the different genders.

\subsection{Main findings:}

Gender is an important factor that affects language production even in standard political speeches. Female politicians tend to have some basic features that are associated with their speeches, and males do have also other features that are also associated with their speeches. Through their political speeches, females tried to resemble men in some areas and deviate in others. Furthermore, the theme of the speech has a clear role affecting the verbal choices of the two genders. The research questions of this study were successfully answered. As for question one; what are the areas of verbal differences between the speakers of both genders? The study had proved a great deal of differences between the verbal choices of both genders. Those verbal differences are listed below in details:

\subsubsection{Differences between female and male speakers}

1- The relational process proved that males' speakers are more into reality concerning their speeches in theme I while females' speakers shifted the role into theme II; they appeared to be more rational than men in theme II.

2- Material process was also another area that highlighted the gender variation theme in this study. As there was a huge gap between the two genders' usages of the material process. Females were way far into activity by using a higher percentage of the material processes in both themes than males.

3- As for the mental process it was found that in theme II male speakers turned to be the highest using the mental verbs which in turn can give an indication on how the topic of speaking has a role in displaying the gender variation theme. Males in theme II are more into cognition, perception and affection than females.

4- Comparing the two genders in dealing with the verbal process, it was found that males focus on their oral production through using the verbal process more than their counter gender. 


\section{Language \& Literature}

As for question two; what are the areas of verbal similarities shared by the speakers of both genders? The study proves another some fields of similarities. Those similarities are listed below.

\subsubsection{Similarities between Females' and Males' speakers}

1- The overall transitivity analysis showed that both genders used the six types of processes in both of the two themes.

2- In of the two themes males and females used the four types of the mental process. In theme I males and females used the mental process with nearly equal percentages which in turn does not give much evidence about the gender variation aspect.

3- Concerning the existential process, it is clear that both females' and males' politicians gave the least priority to the existential process it. The existential process was used in the last rank of all the other six processes by both genders in the two themes.

As for research question three; what are the process types affected by the change of the theme of speech? The study proved that: the change of the topic of speaking has an important role affecting both genders verbal choices. The topic of nomination acceptance proved to be different from that tackling women's roles and feminine issues in societies. Transitivity analysis shows results that are related to the topic of speaking. The difference which is attached to the topic of speaking was in the relational process, the behavioral processes and the mental process. Females used less of the relational process in theme I, which turned to be the highest in theme II. Males used less behavioral verbs in theme I, than females, but in theme II, males mounted to use higher than their counterpart. Concerning the mental process, the study had proved that in theme I, both genders were nearly equal. However, in theme II, the topic played a recognizable role, in which male speakers mounted and deviated from females and used a higher percentage of that process. 
Buhuth Journal

Language \& Literature

\subsection{Recommendations for further studies}

This study has investigated the speeches of eight different gendered politicians. The main scope of this study was to prove gender a factor that affects language production even in standard public political speeches. The eight politicians were chosen from different areas of the world but the speeches were chosen to be only voiced in English. Therefore, other languages might be potential texts for investigations in the future. Moreover, the study here analyzed the political texts following only Halliday's transitivity. Consequently, Halliday's mood, modality, pronouns and cohesion are further areas that future researchers can apply to get comprehensive results. 


\section{Buhuth Journal \\ Language \& Literature}

Second Issue- part two (2021)

\section{References}

Adelakun, T. (2014). A corpus-based critical discourse analysis of election news in Nigerian newspapers. University Annual Review of Anthropology of Birmingham. M.Phil.

Anna, V. (2018). Gender Discourse on Politicians in News Writing: A Corpus Study. University of Turku.

Bang, M. (2003). A corpus based study of representation of foreign countries in the South Korean Press. : https://www.researchgate.net/publication/277750787.

Biber D. \& Burges J. (2000). Historical Change in the Language use of women and men. Volume: 28 issue: 1, published: March 1, 2000.

Biber, D. Conrad, S. Reppen, R. (1998). Corpus linguistics. Investigating language structure and use. Cambridge university press.

Blommaert, J., \& Bulaen, C. (2000). Critical discourse analysis. 29, 447-66 Božić, D (2016). Gender differences in the political speeches from the 13th United States congress.

Bryman, A. (2001). Social Research Methods. Oxford University Press. https://books.google.com.eg/books?id=3ulxQgAACAAJ

Chappell, P. (2013). An introduction to systemic functional grammar. https://henrickoprea.com/2013/02/07/an-introduction-to-systemic-functional-grammarby-phil-chappell/.

Childs, S. (2000). The new labour women MPs in the 1997 British parliament: Issues of recruitment and representation, Women's History Review. 9:1, 55-73, DOI: 


\section{Buhuth Journal \\ Language \& Literature}

$10.1080 / 09612020000200228$.

Cristina, B. (2001). Why can't women talk like a man? An investigation of gender in the play Pygmalion by Bernard Shaw. https://core.ac.uk/download/pdf/30361303.pdf

Crystal, D. Indonesian Journal of Applied Linguistics. (2008). A Dictionary of Linguistics and Phonetics. (6 ${ }^{\text {th }}$ ed.), Blackwell, London. 978-1-405-15296-9. http://ndl.ethernet.edu.et/bitstream/123456789/36901/1/8..pdf

Dahbi, M. (2003). Gender Differences in Language? An Investigation of GenderRelated Differences in Classroom Conversations, Munich, GRIN Verlag, https://www.grin.com/document/294150.

Danijel, T. (2014). Corpus-based analysis of political speeches of warfare by Bush and Obama.

file:///C:/Users/Micro/Downloads/Corpus_based_analysis_of_political_speec.pdf

De Vaus, D. A. (2014). Surveys in Social Research. (6 ${ }^{\text {th }}$ ed.). UCL Press.

Eggins, S. (2011). An introduction to systemic functional linguistics. (2nd ed.). Continuum international publishing group.

Emilia, E. \& Yunita, N. \& Laela,I. (2017). Gender in EFL classroom: Transitivity analysis in English textbook for Indonesian students. Indonesian journal of applied linguistics. 7. 206. 10.17509/ijal.v7i1.6877.

Emilia, E. (2014). Introduction Functional Grammar. ISBN 978-979-429-427-0. Fairclough, N. (1993). Discourse and Social Change. USA: Blackwell.

Fowler, R., Hodge, B., Kress, G., \& Trew, T. (1979). Language and Control. Routledge. 


\section{Buhuth Journal Language \& Literature}

Gerot, L. and Wignell, P. (1994). Making Sense of Functional Grammar. Stabler.

Halliday, M. A. K. (1978). Language as Social Semiotics. Edward Arnold.

Halliday, M. A. K. (1985). An Introduction to Functional Grammar. Arnold.

Halliday, M. A. K. (1994). An Introduction to Functional Grammar. Edward Arnold Halliday, M.A.K \& Matthiessen, M.I.M. (2004). An introduction to functional grammar (3rd edition). Arnold.

Halliday, M.A.K. (1994). An Introduction to Functional Grammar. 2nd Edition. London: Edward Arnold.

Halliday. M.A.K. (2014). Halliday's introduction to functional grammar. ( $4^{\text {th }}$ ed.) by Routledge.

Khumairoh, E. (2017). Exploring transitivity system in narrative test titled "Goose Girl" by Hekena I.R. Agustien of grade XII senior high school in learners textbook (English for a better life).

Kilgarriff, A. Baisa, V. J Bušta, V. Jakubícek, M. Kovár, V., Michelfeit, J. Rychlý, P. Suchomel, V. (2014): The Sketch Engine: ten years on. In Lexicography 1(1): 7-36. DOI: 10.1007/s40607- 014-0009-9. ISSN 2197-4292.

Kilgarriff, A. Marcowitz, F. Smith, S. Thomas, J. (2015). Corpora and Language Learning with the Sketch Engine and SKELL. Revue Francaise de Linguistique Appliquee. 20. 61-80. 10.3917/rfla.201.0061

Kress, G., \& Hodge, R. (1979). Language as Ideology. Routledge. 


\section{Language \& Literature}

Kurniani, E. O. (2017). Transitivity analysis in the Friday sermon delivered by Mufti Ismail Ibn Musa Menk on September 27th, 2013, (Doctoral dissertation, DIAN NUSWANTORO UNIVERSITY).

Leech, G. (1992). Corpora and theories of linguistic performance. In J. Startvik (Ed.), Directions in corpus linguistics (pp. 105-122). Mouton de Gruyter.

Martin, J.R. Mathiessen, M. I. M. and Painter, C. (1997). Working with functional grammar.

Mathiessen, C. Halliday, M.A.K. (1997). Systemic functional grammar: A first step into the theory.

Merriam-Webster. (n.d.). KWIC. In Merriam-Webster.com dictionary. Retrieved December 11, 2020, from https://www.merriam-webster.com/dictionary/KWIC.

Mullet DR. (2018). A General Critical Discourse Analysis Framework for Educational Research. Journal of Advanced Academics. 2018;29(2):116-142. doi:10.1177/1932202X18758260.

Najeem, T. (2017). Grammar and Gender: A Comparative Study of the Integration and Organisation of Meanings in Selected Male and Female-authored Prose works. doi:10.7575/aiac.ijalel.v.6n.1p.275

URL: http://dx.doi.org/10.7575/aiac.ijalel.v.6n.1p.275.

Nordquist, R. (2020). "Linguistic Variation." ThoughtCo, Aug. 26, 2020, thoughtco.com/what-is-linguistic-variation-1691242.

North, H. (2014). The Discourse Analysis of United States Foreign Policy towards Iraq and Egypt (Master's thesis). Masaryk University. 
Buhuth Journal

Second Issue- part two (2021)

\section{Language \& Literature}

Pekosy,E. \& Harmaoglu, O. (2017). Corpus Based Authenicity Analysis of Language Teaching Course boo. International Journal of Languages Education and Teaching. Volume5, Issue4, December 2017, p.287-307. Doi 10.18298/ijlet.2324

Rayhan, M. (2011). Analyzing clause by Halliday's transitivity system. Jurnal Ilmu Sastra vol.6n No.1.

Risberg, G., Hamberg, K. \& Johansson, E.E. (2006). Gender perspective in medicine: a vital part of medical scientific rationality. A useful model for comprehending structures and hierarchies within medical science. BMC Med 4, (20) https://doi.org/10.1186/1741-7015-4-20.

Romaniuk, T. (2016). On the relevance of gender in the analysis of discourse: A case study from Hillary Rodham Clinton's presidential bid in 2007-2008. Discourse \& Society. 27(5):533-553. doi:10.1177/0957926516651221.

Schubert, L. (2020)."Computational Linguistics", The Stanford Encyclopedia of Philosophy (spring $2020 \quad$ Edition), Edward N. Zalta (ed.), URL $=<$ https://plato.stanford.edu/archives/spr2020/entries/computational-linguistics/ $>$.

Schwartz, H. \& Eichstaedt, J. \& Dziurzynski, L. \& Kern, M. \& Blanco, E. \& Kosinski, M. \& Stillwell, D. \& Seligman, M. \& Ungar, L. (2013). Toward Personality Insights from Language Exploration in Social Media. AAAI Spring Symposium. Association for the Advancement of Artificial Intelligence.

Shaw, S. (2002) Language and gender in political debates in the House of Commons. Doctoral thesis, Institute of Education, University of London.

Sheyholislami,

J.(2015).

Critical

Discourse Analysis. https://www.researchgate.net/profile/Jaffer_Sheyholislami/publication/228921006_Cri tical_discourse_analysis/links/54a999720cf2eecc56e6c591.pdf. 
Stubbs, M. (2001). Words and Phrases: Corpus Studies of Lexical Semantics. Blackwell Publishers, xix+267pp, paperback ISBN 0-631-20833-X, USD 39.95 / GBP 16.99. Announced in http://linguistlist.org/issues/13/13-436.html.

Thi, N. T., Van, P. H., and Huu, T. P. (2017). Halliday's functional grammatical philosophical foundation and epistemology. Volume 29, University of Da Nang, Vietnam

Thompson, G. (1996). Introducing Functional Grammar. Being: Foreign Language Teaching and Research Press, 78.

Totibadze, S. (2017). Most Frequently Used Gendered Metaphors in British Political Discourse. Leiden University.

https://studenttheses.universiteitleiden.nl/handle/1887/49717

Wang, J. (2010). A Critical Discourse Analysis of Barack Obama's Speeches, Journal of Language Teaching and Research, Vol. 1, No. 3, pp. 254-261, May 2010 (C) 2010 ACADEMY PUBLISHER Manufactured in Finland. doi:10.4304/jltr.1.3.254-261.

Williamson, K .Given, L.M. Scifleet, P. (2018). Qualitative data analysis. Editor(s): Kirsty Williamson, Graeme Johanson. Research Methods (Second Edition). Chandos Publishing, ISBN 9780081022207, https://doi.org/10.1016/B978-0-08-1022207.00019-4.

Wodak, R. (2001). What CDA is about - a summary of its history, important concepts and its developments.

Xia, X. (2013). Gender Differences in Using Language. Theory and Practice in Language Studies. 3. 10.4304/tpls.3.8.1485-1489. 


\section{Buhuth Journal \\ Language \& Literature}

Second Issue- part two (2021)

Yan, F. (2005). System Function Grammar and Discourse Analysis [J] Foreign Language Teaching.

Yujie, Z. and Fengjie, L. (2018). Transitivity Analysis of American President Donald Trump's Inaugural Address. International Journal of Literature and Arts. 6 (2) 28-34. doi: 10.11648/j.ijla.20180602.11.

Yumin, C. (2009). Interpersonal meaning in textbooks for teaching English as a foreign language in China: A multi-model approach. University of Sydney.

Żemojtel, M. Marganski,A. Baran, T. and Piotrowski, J. (2017). Corruption and Sexual Scandal: The Importance of Politician Gender. vol. 33, ${ }^{\circ} 1$ (january), 133-14.

Żemojtel, M. Marganski,A. Baran, T. and Piotrowski, J. (2017). Corruption and Sexual Scandal: The Importance of Politician Gender. vol. 33, $\mathrm{n}^{\circ} 1$ (january), 133-14 